\title{
Special Distribution of Crude Oil in the Lucaogou Formation in Jimusaer Sag and Genetic Analysis of Its Physical Difference
}

\author{
Ming Wang, ${ }^{1}$ Shiju Liu, ${ }^{2,3}$ Ji Li, ${ }^{1}$ Gang Gao $\mathbb{D}^{2,3}$ Julei Mi, ${ }^{1}$ and Erting Li ${ }^{1}$ \\ ${ }^{1}$ Xinjiang Key Laboratory of Shale Oil Exploration and Development, CNPC, Karamay 834000, China \\ ${ }^{2}$ State Key Laboratory of Petroleum Resources and Prospecting, China University of Petroleum (Beijing), Beijing 102249, China \\ ${ }^{3}$ College of Geosciences, China University of Petroleum (Beijing), Beijing 102249, China
}

Correspondence should be addressed to Gang Gao; gaogang2819@sina.com

Received 13 October 2020; Revised 17 January 2021; Accepted 26 January 2021; Published 24 February 2021

Academic Editor: Yi-Dong Cai

Copyright (c) 2021 Ming Wang et al. This is an open access article distributed under the Creative Commons Attribution License, which permits unrestricted use, distribution, and reproduction in any medium, provided the original work is properly cited.

\begin{abstract}
The shale oil of the Lucaogou Formation in the Jimusaer Sag of the Junggar Basin was divided into two sweet spots for exploration and development. Crude oil in the upper and lower sweet spots comes from the upper and lower source rocks. After years of exploration, it has been found that the crude oil in the lower sweet spot has worse physical properties than that of the upper sweet spot. In this study, through the physical and geochemical analysis of crude oil in the upper and lower sweet spots, combined with the organic petrological observation of the upper and lower source rocks, the cause of the poor physical properties of the crude oil in the lower sweet spot has been identified. $n$-Alkanes in the saturated hydrocarbons of crude oil in the upper and lower sweet were complete while odd-to-even predominance was evident, indicating that the poor physical properties of the crude oil are unrelated to biodegradation. In addition, the correlation between the biogenic parameters and the physical properties of crude oil was analyzed, finding that the difference in crude oil is mainly related to the composition of biogenic precursors of upper and lower source rocks. Combined with organic petrological observation, the lower source rock was found to be rich in telalginite (green algae), which is therefore the primary reason for the difference in physical properties. In comparing results from the characteristics of crude oil biomarkers from both the upper and lower sweet spots, crude oils in the upper sweet spot are similar to each other, indicating that the enrichment of crude oil has experienced a certain migration. In contrast, the differences in biomarkers between the crude oils of the lower sweet spot were relatively large and changed regularly with depth, suggesting the self-generated and self-stored characteristics of crude oil enrichment. At the same time, it was found that the crude oil in the lower sweet spot is also affected by the maturity of adjacent source rocks under the condition of a consistent parent material source. Overall, it was determined that the lower the maturity of source rocks, the poorer the physical property of the crude oil produced.
\end{abstract}

\section{Introduction}

The Lucaogou Formation in the Jimusaer Sag of the Junggar Basin is of great significance for shale oil exploration and development in China ([1]; Zhu et al., 2019; [2]). Many scholars have carried out research into shale oil accumulation in the Lucaogou Formation [3, 4], while some scholars have investigated the hydrocarbon potential of source rocks, and consider the source rocks of Lucaogou Formation as the best lacustrine source rocks in the world [5-8]. Many scholars have also researched the lithology, storage space, and pore structure of the reservoir ( $\mathrm{Li}$ et al., 2013; [3, 9-11]). In the course of exploration, the Lucaogou Formation was divided into upper and lower sweet spots (i.e., reservoirs), which are the primary targets for the exploration and exploitation of shale oil resources. Crude oil in the upper and lower sweet spots comes from the upper and lower source rocks $[3,12]$. Interestingly, the inversion of the physical properties of crude oil revealed that crude oil in lower sweet spot has poorer physical properties than crude oil in the upper sweet spot. Moreover, the physical properties of crude oil in the same sweet spot layer are internally different, which has caused problems in the shale oil extraction scheme. In this study, through the physical and geochemical analysis of crude oil 


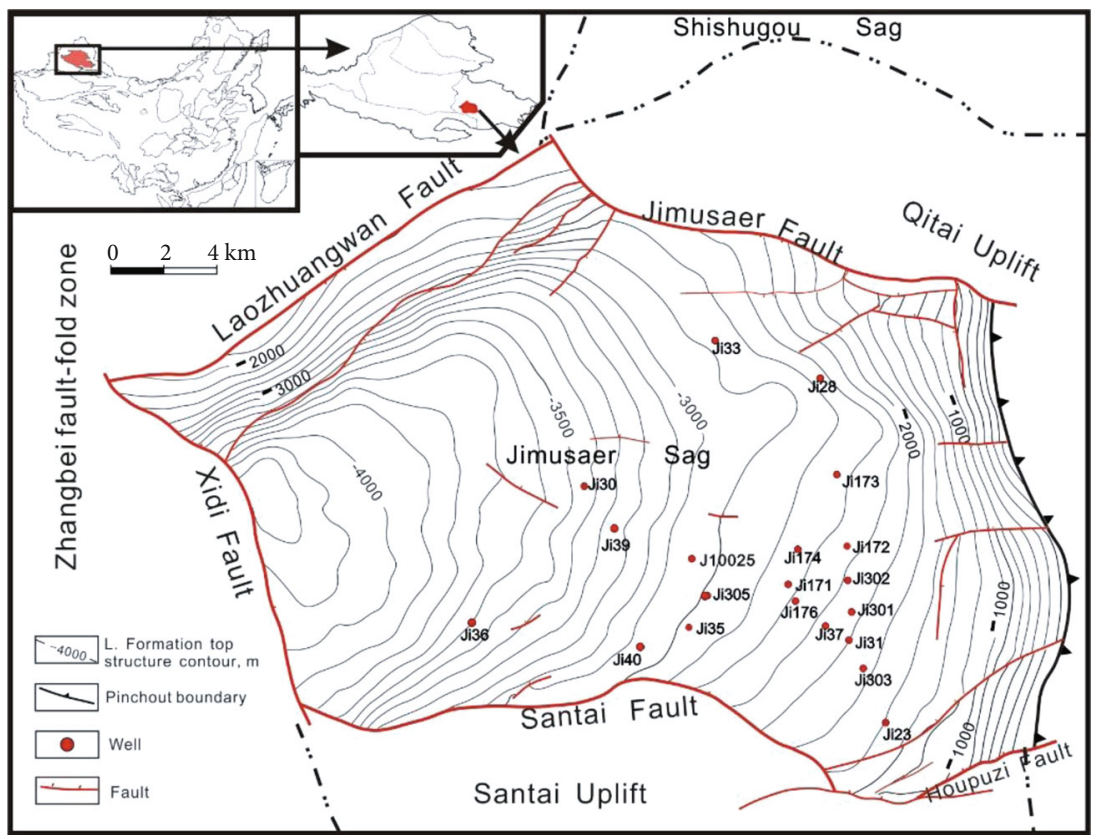

FIgURE 1: Structural location map of Jimusaer Sag.

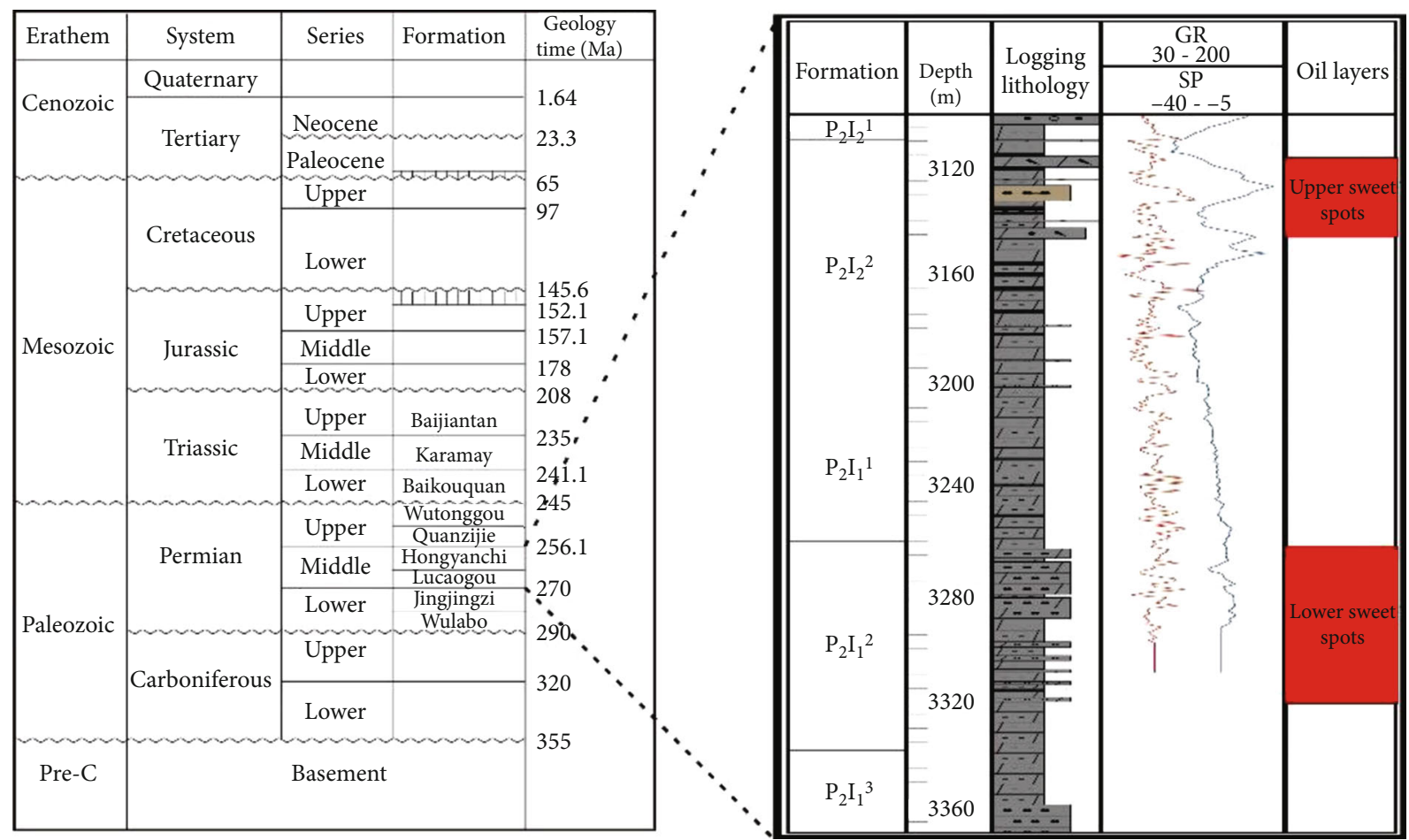

FIgURE 2: Stratigraphic column of the Lucaogou Formation in Jimusaer Sag.

in the upper and lower sweet spots, combined with organic petrological observation of the upper and lower source rocks, the causes of oil thickening were studied.

\section{Geological Setting}

The Junggar Basin, located on the Kazakhstan Plate and considered an important feature of the central Asian orogenic belt, is a large petroliferous basin in western China (Yang et al., 2014; [13]). The Jimusaer Sag, located in the southwest margin of the eastern uplift of the basin, has an area of approximately $1,300 \mathrm{~km}^{2}$. The northern, southern, and western sides of the sag are all bounded by faults, and the sedimentary strata in the east gradually pinch out in the Guxi Uplift (Figure 1). The sag, being controlled by the surrounding boundary faults and the tectonic pattern of its 


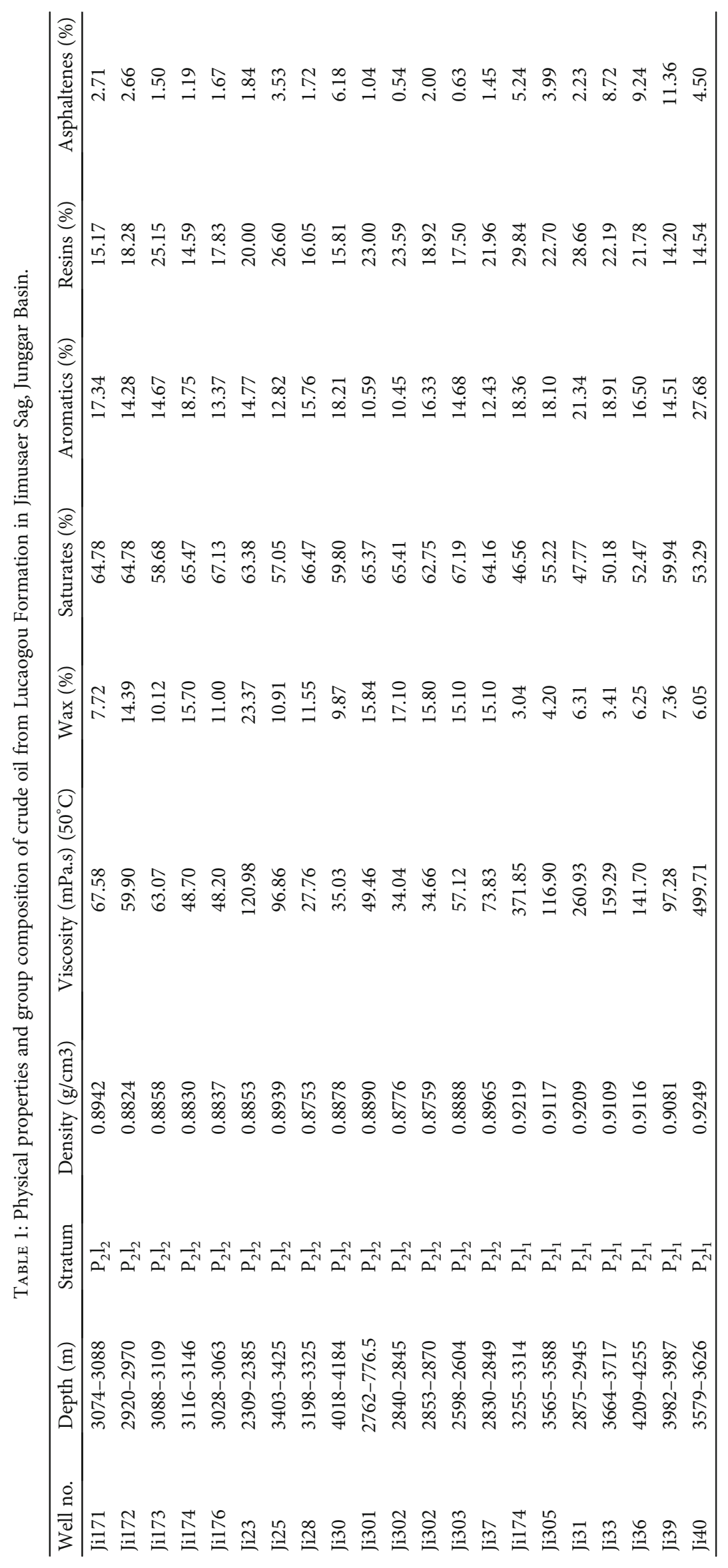


Carboniferous basement, is dustpan-shaped with a western fault and eastern overpass $[13,14]$.

The Middle Permian Lucaogou Formation is a compositionally diverse set of fine-grained mixed sedimentary rocks [15] including terrigenous clastics, volcanic material, and intrabasinal carbonate rocks. The rock types are complex, including mudstone, siltstone, dolomite, and pyroclastic rocks [16]. The source rocks have high organic matter abundance and good organic matter type, have reached the oil generation window, and are well distributed throughout the sag [16, 17]. The reservoir is mainly distributed in the "sweet spot" between the first two-layer formation $\left(\mathrm{P}_{2} \mathrm{l}_{1}{ }^{2}\right)$ and second two-layer formation $\left(\mathrm{P}_{2} \mathrm{l}_{2}{ }^{2}\right)$ of the Lucaogou Formation (Figure 2), which belongs to a typical tight reservoir $[3,4,18,19]$.

\section{Samples and Methods}

3.1. Sample Collection. A total of 21 crude oil samples were collected from the Lucaogou Formation in the Jimusaer Sag, including seven samples from the lower sweet spot (Figure 1) and the remaining from the upper sweet spot of the Lucaogou Formation (Figure 1). In addition, four mudstone core samples were selected for organic petrology observation.

3.2. Physical Analysis of Crude Oil. Density, viscosity, and wax contents were provided by the Xinjiang Oilfield Company.

3.3. Petrographic Analysis. The polished blocks for microscopic examination were ground and polished on a Buehler automatic grinding and polishing machine (EcoMet 250 with AutoMet 250) to obtain a smooth surface that was perpendicular and parallel to the bedding. Maceral observations were carried out using a Leica microscope under both reflected and fluorescent lights.

3.4. Crude Oil Separation, Gas Chromatography, and Gas Chromatography-Mass Spectrometry. Asphaltenes were filtrated using preextracted cotton wool, and then, the maltenes were fractionated into aliphatic and aromatic fractions and polar compounds by column chromatography over activated silica gel and alumina.

Saturated fractions were then extracted using a chloroform/methanol solution $(87 / 13$, vol. \%) for a total of $72 \mathrm{~h}$ and prepared for GC (gas chromatography) and GC-MS (gas chromatography-mass spectrometer) analysis by using a GC instrument (HP-5MS column) and a Trace DSQ II GC/MS (TR-5MS capillary column). The GC analysis used an HP6890 gas chromatograph equipped with a $30 \times 0.32$ mm i.d. HP-5 column with a film thickness of $0.25 \mu \mathrm{m}$, and $\mathrm{N}_{2}$ was used as the carrier gas. The GC oven temperature was initially held at $80^{\circ} \mathrm{C}$ for $5 \mathrm{~min}$ before being ramped from 80 to $290^{\circ} \mathrm{C}$ at $4^{\circ} \mathrm{C} / \mathrm{min}$ and then held for $30 \mathrm{~min}$. The GC-MS analysis was conducted with an Agilent 5973I mass spectrometer interfaced with an HP6890 gas chromatograph equipped with the same type of column used during GC analysis, and He was used as the carrier gas. The GC oven temperature during the GC-MS analysis was initially held at $60^{\circ} \mathrm{C}$ for $5 \mathrm{~min}$ before being ramped to $120^{\circ} \mathrm{C}$ at $8^{\circ} \mathrm{C} / \mathrm{min}$, then from 120 to $290^{\circ} \mathrm{C}$ at $2^{\circ} \mathrm{C} / \mathrm{min}$, and then held at $290^{\circ} \mathrm{C}$ for $30 \mathrm{~min}$.

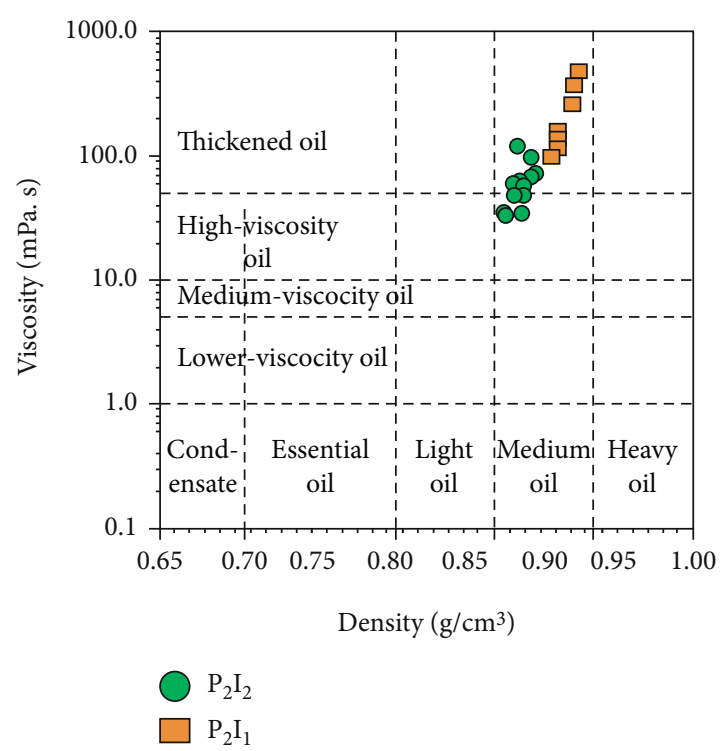

Figure 3: Cross-plots of density versus viscosity.

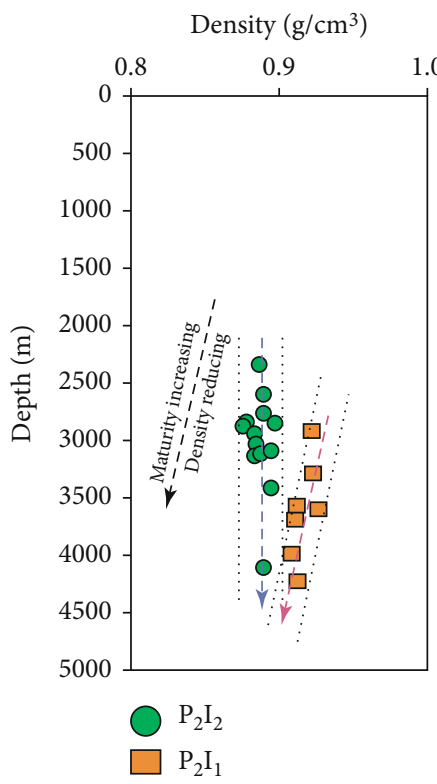

(a)

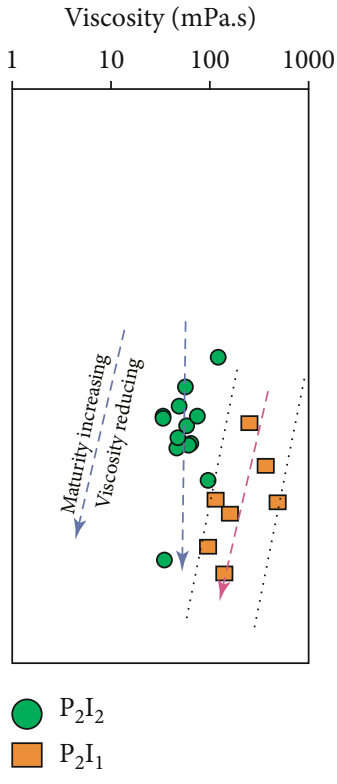

(b)
Figure 4: Cross-plots of (a) density versus depth and (b) viscosity versus depth.

\section{Results}

4.1. Physical Properties and Group Composition of Crude Oil. Physical characteristics of the crude oil are shown in Table 1. The crude oil in the upper sweet spot had a density of 0.8753 $0.8965 \mathrm{~g} / \mathrm{cm}^{3}$ (average of $0.8857 \mathrm{~g} / \mathrm{cm}^{3}$ ), a viscosity of $27.76-$ $120.98 \mathrm{mPa} . \mathrm{s}$ (average of $58.37 \mathrm{mPa} . \mathrm{s}$ ), and a wax content of $3.04-7.36 \%$ (average of 5.23\%). The crude oil in the lower sweet spot was characterized by a density of $0.9081-$ $0.9249 \mathrm{~g} / \mathrm{cm}^{3}$ (average of $0.9157 \mathrm{~g} / \mathrm{cm}^{3}$ ), a viscosity of 97.28-499.71 mPa.s (average of $235.38 \mathrm{mPa} . \mathrm{s}$ ), and a wax content of $7.72-23.37 \%$ (average of $13.83 \%$ ). The crude oils 


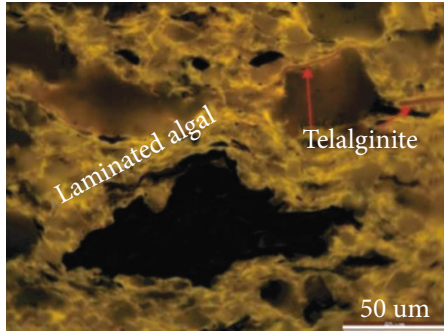

(a)

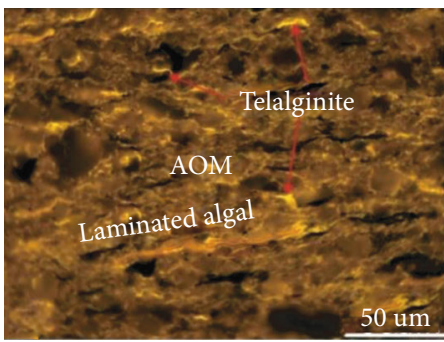

(c)

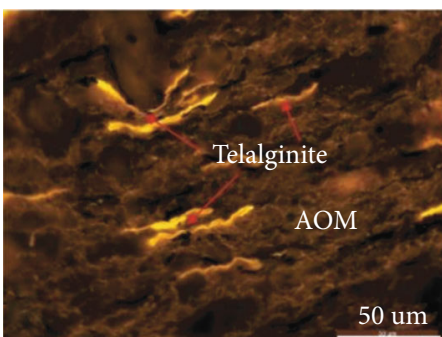

(e)

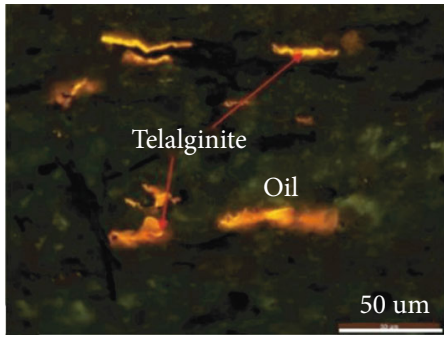

(g)

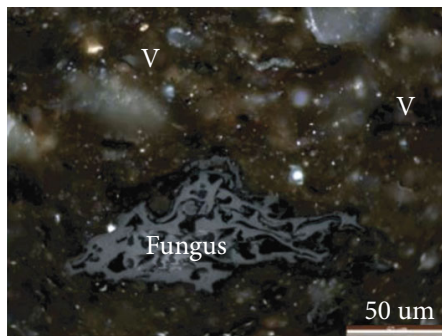

(b)

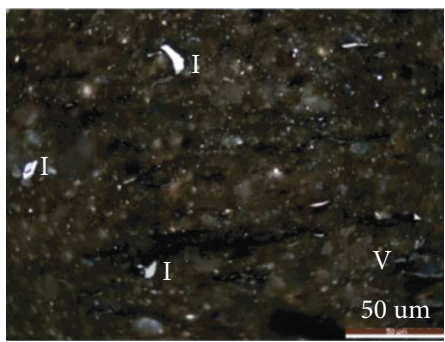

(d)

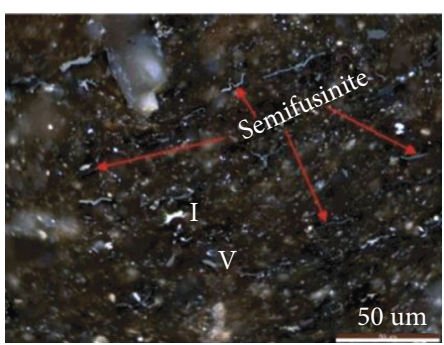

(f)

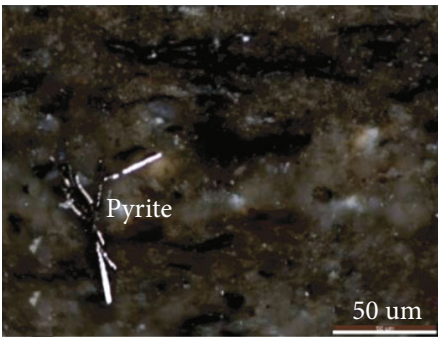

(h)

Figure 5: Photomicrographs showing AOM, V, I, laminated algal, telalginite, semifusinite, fungus, oil, and pyrite in the Permian Lucaogou sediments from the Junggar Basin: (a) fluorescent light, J10025, 3586.2 m, shale; (b) same field as (a) under reflected light; (c) fluorescent light, J10025, 3600.5 m, shale; (d) same field as (c) under reflected light; (e) fluorescent light, J10025, 3670.1 m, shale; (f) same field as (e) under reflected light; (g) fluorescent light, J10025, $3675.25 \mathrm{~m}$, shale; (h) same field as (g) under reflected light.

from $\mathrm{P}_{2} \mathrm{l}_{1}$ were characterized by high density, high viscosity, and low wax content. In general, crude oil in the Lucaogou Formation has a higher density, and the density and viscosity of crude oil in the lower sweet spot were both greater than those of crude oil in the upper sweet spot, which belong to the category of heavy oil (Figure 3). As the depth increased, the density and viscosity of the crude oil in the upper and lower sweet spots were greater, yet crude oil in the lower sweet spots was more evident (Figure 4).

The gross compositions (SARA) of the oils from the Jimusaer Sag are given in Table 1. The saturated hydrocarbon fractions for crude oils from $\mathrm{P}_{2} \mathrm{l}_{2}$ were in the range of 57.05$67.19 \%$, with a relatively low content of resins (14.59-26.6; average $=19.6)$ and asphaltenes $(0.54-6.18$; average $=2.05)$ (Table 1). Crude oils from $\mathrm{P}_{2} \mathrm{l}_{1}$ were characterized by a relatively high content of resins $(14.2-29.84$; average $=21.99)$ and asphaltenes $(2.23-11.36$; average $=6.47)$ (Table 1$)$.

4.2. Organic Petrology. Telalginite (green algae) can be observed in the source rock samples from the upper and lower sweet spots (Figure 5). This telalginite, which has also been reported in the Lucaogou Formation in the Santanghu Basin [20], has a special biological structure (Figures 5(e) and $5(\mathrm{~g}))$. Comparatively speaking, the telalginite in the source rock samples from the lower section was relatively developed, while the laminated algae in the upper section of 

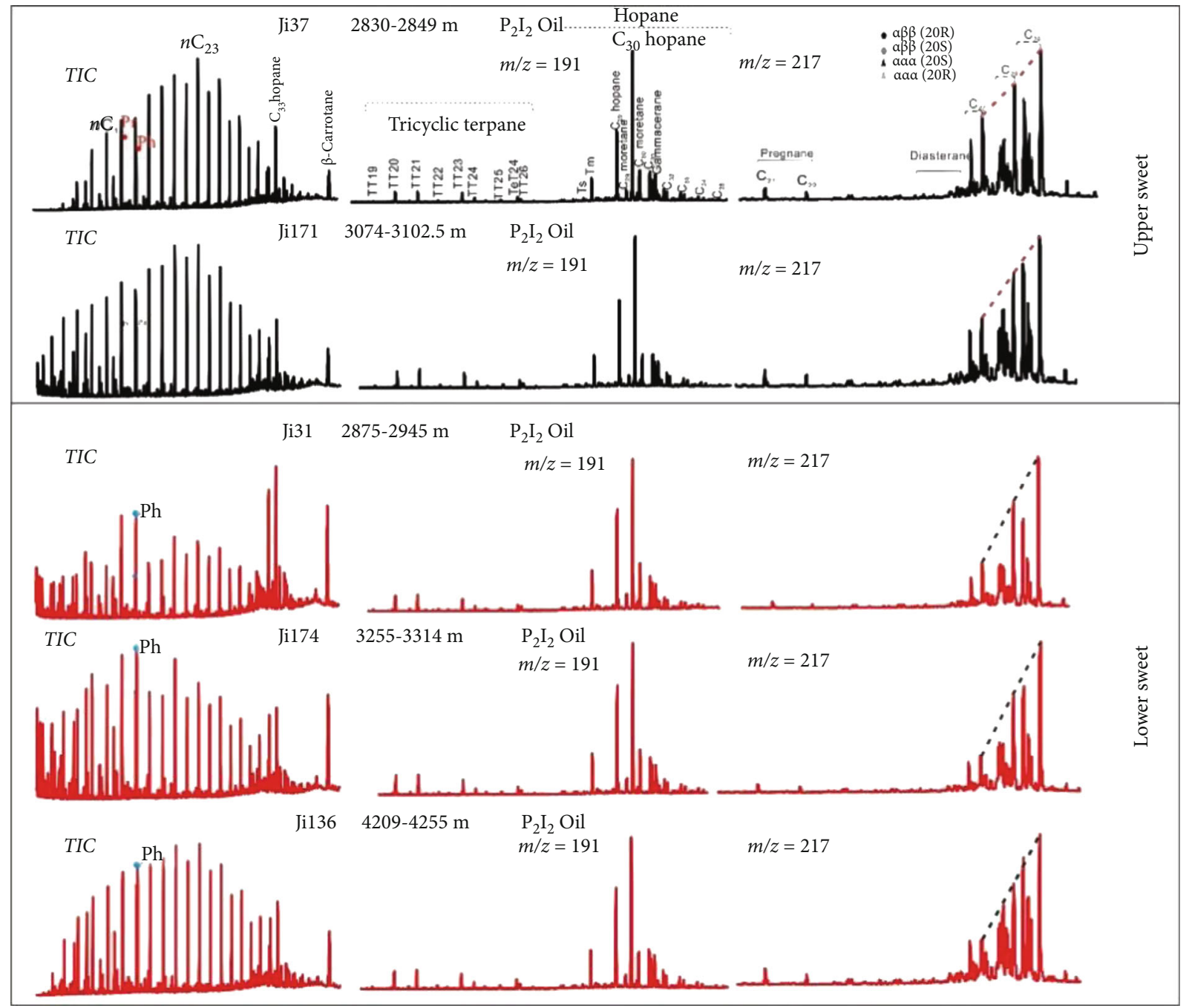

FIGURE 6: Gas chromatography (GC) and gas chromatography-mass spectrometry (GC-MS) data for the crude oil in the Lucaogou Formation, Jimusaer Sag.

the sample were relatively high in terms of content (Figure 5). Semifusinite was relatively common in the sample (Figure $5(\mathrm{f}$ ) ). Furthermore, fungi can also be occasionally observed (Figure 5(b)). AOM (amorphous organic matter), identified as the hydrocarbon-generating component in each sample (Figures 5(c) and 5(e)), is an amorphous fine-grained organicinorganic matter mixture and is the predominant organic component of the Lucaogou Formation. AOM is derived from phytoplankton or terrestrial organic components after intensive degradation [21]; therefore, it can only be observed under fluorescent light with bright yellow fluorescence. Acicular pyrite with a particular morphology and green fluorescent oil can also be seen in the core samples (Figure 5(h)).

4.3. Molecular Geochemical Characteristics. Multiple molecular compounds were identified in the 21 crude oil samples, including normal alkanes, isoprenoids, terpanes, and steranes. The total ion current (TIC) of sterane $m / z=217$ and terpane $m / z=191$ fragmentograms from gas chromatography-mass spectrometry (GC-MS) of the saturated fraction for source rocks and crude oil samples is plotted in Figure 6. The param- eters of saturated hydrocarbons, terpanes, and steranes are shown in Table 2.

\section{Discussion}

The major factors affecting the physical properties of crude oil are the active rock hydrocarbon-parent material combination, source rock maturity, migration, and secondary biodegradation $[22,23]$.

5.1. Effects of Biodegradation on the Physical Properties of Crude Oil. The deterioration of the physical properties of crude oil discovered in many basins is typically related to biodegradation, and the degree of degradation can usually be determined from the characteristics of the crude oil biomarkers. With the intensification of biodegradation, the sequence of biomarker compounds that are degraded in saturated hydrocarbons is as follows: $n$-alkane $\rightarrow i$-alkane $\rightarrow$ regular sterane $\rightarrow$ pentacyclic triterpene $\rightarrow$ tricyclic triterpene $\rightarrow$ rearranged sterane $\rightarrow 25$ descending hopane $\rightarrow \mathrm{Tm} \rightarrow$ gammacerane (Alexander et al., 1983; [22, 24]; Seifert et al., 1984; Howell et al., 1986; [25]). 


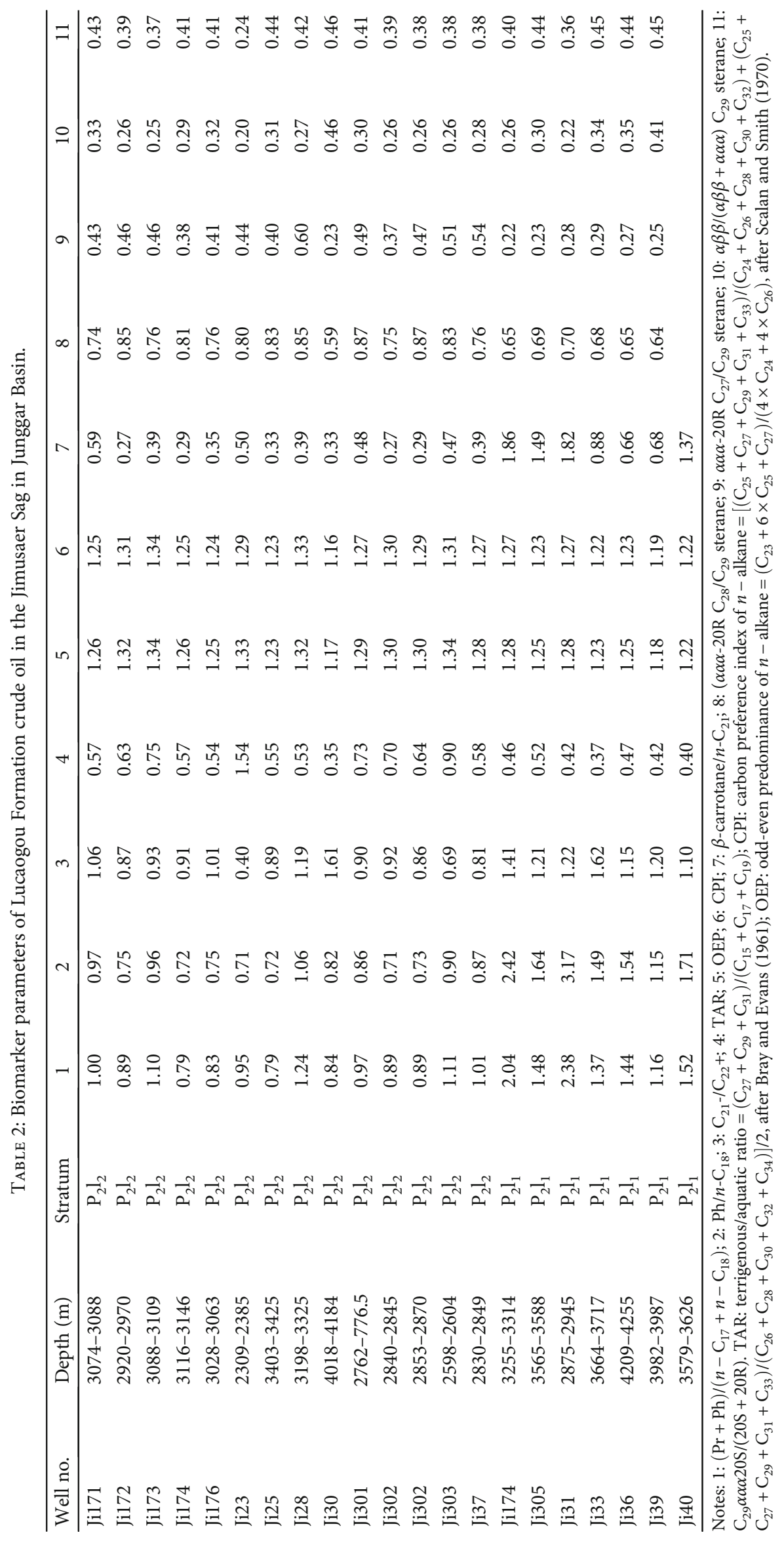




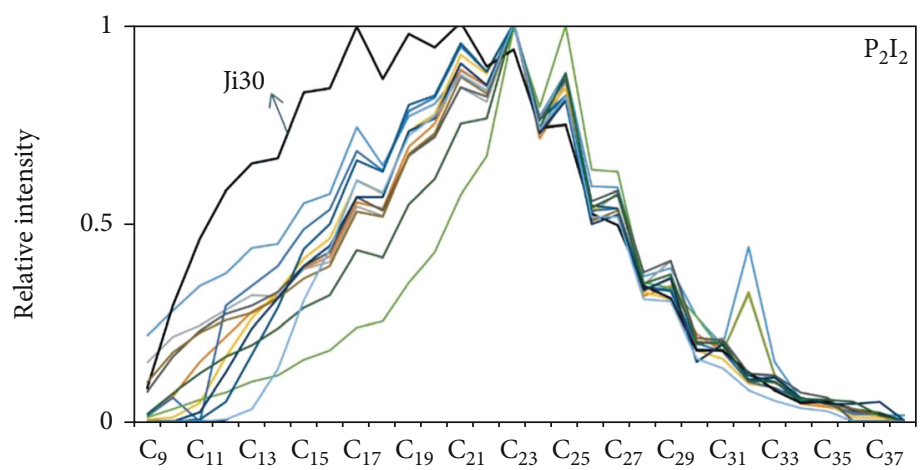

(a)

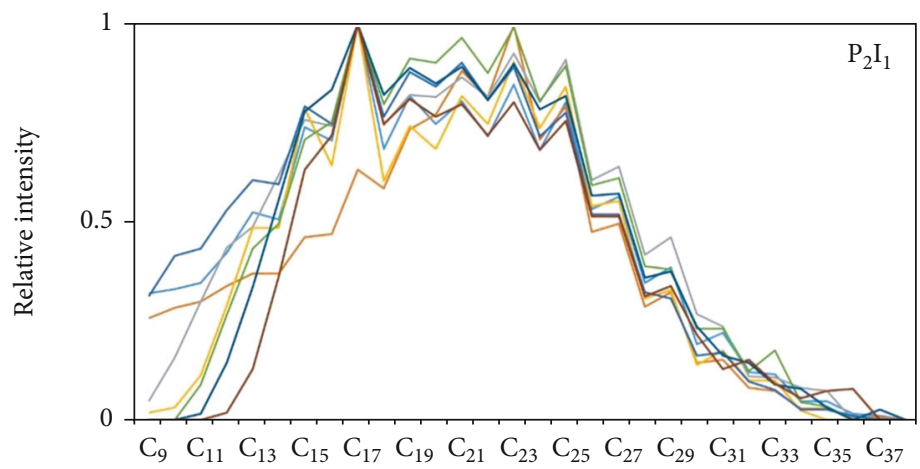

(b)

Figure 7: Distribution curve of $n$-alkanes of the (a) upper and (b) lower sweet crude oils in the Lucaogou Formation, Jimusaer Sag.

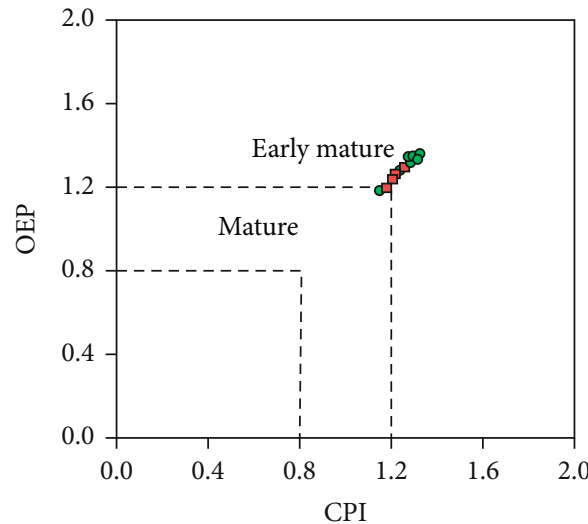

$\mathrm{P}_{2} \mathrm{I}_{2}$

$\mathrm{P}_{2} \mathrm{I}_{1}$

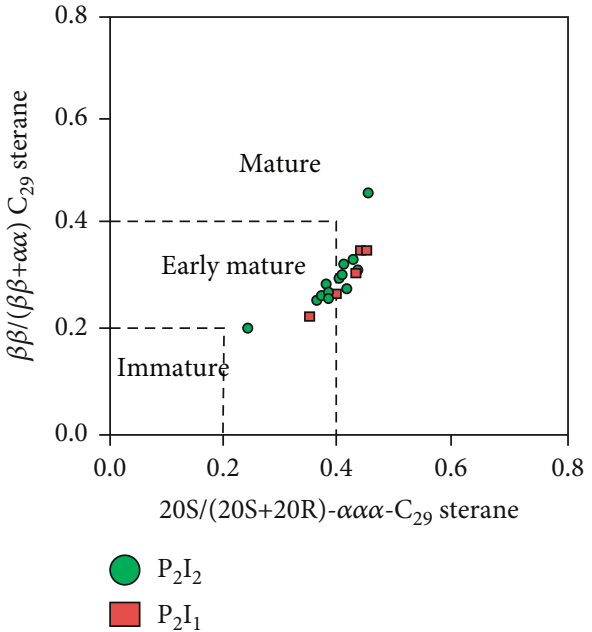

(b)

Figure 8: Cross-plots of (a) CPI versus OEP (after Bray and Evan, 1961) and (b) $\alpha \alpha \alpha-20 \mathrm{~S} /(20 \mathrm{~S}+20 \mathrm{R})$ C29 sterane ratio versus $\alpha \beta \beta /(\alpha \beta \beta+\alpha \alpha \alpha)$ C29 sterane ratio [30] of the crude oil sample in the Lucaogou Formation.

As shown in Figure 6, the $n$-alkanes of saturated hydrocarbons of crude oil from the upper and lower sweet spots remained relatively intact, showing no evident degradation. Figure 7 shows the distribution curve of normal alkanes of crude oil. It can be clearly seen that the normal alkanes of crude oil from both sweet spots have an evident odd-to-even predominance. This further explains the lack of biodegradation of crude oil in the study area.
5.2. Effects of Parent Material Composition on the Physical Properties of Crude Oil. The physical properties of hydrocarbons generated from source rocks with different parental rock compositions are comparably different. For example, the crude oil produced by source rock with organic matter substantially derived from higher plants is generally lighter [26]. Moreover, the physical properties of crude oil produced by the same type of source rock in different evolution stages can 


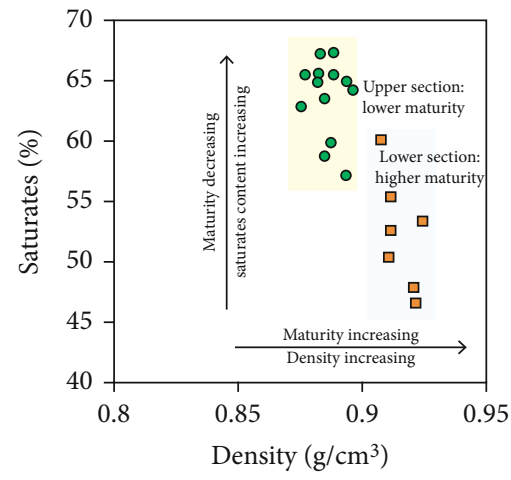

$\mathrm{P}_{2} \mathrm{I}_{2}$

$\mathrm{P}_{2} \mathrm{I}_{1}$

(a)

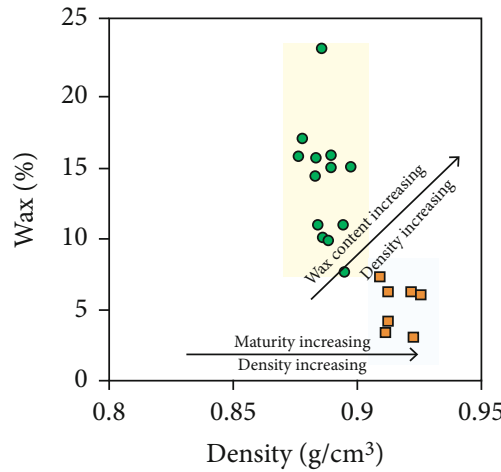

$\mathrm{P}_{2} \mathrm{I}_{2}$

$\mathrm{P}_{2} \mathrm{I}_{1}$

(c)

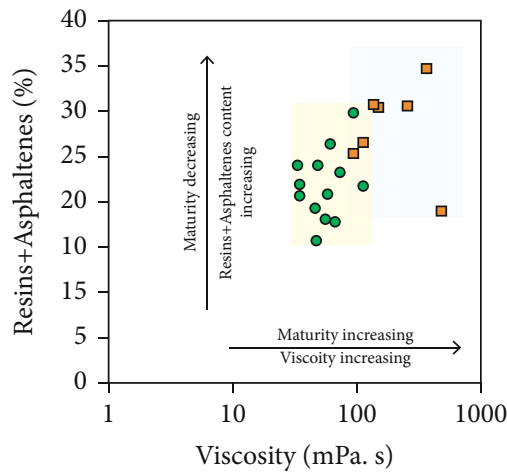

$\mathrm{P}_{2} \mathrm{I}_{2}$

$\mathrm{P}_{2} \mathrm{I}_{1}$

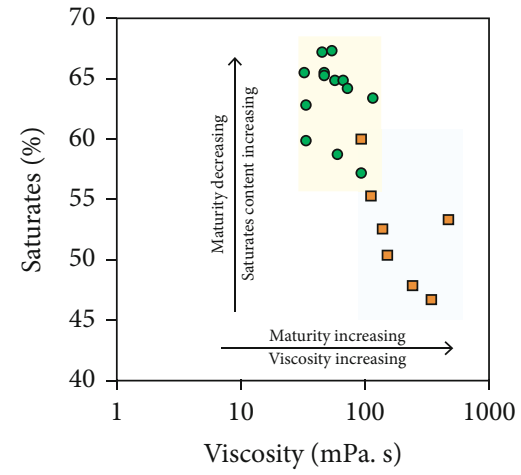

$\mathrm{P}_{2} \mathrm{I}_{2}$

$\square \mathrm{P}_{2} \mathrm{I}_{1}$

(b)

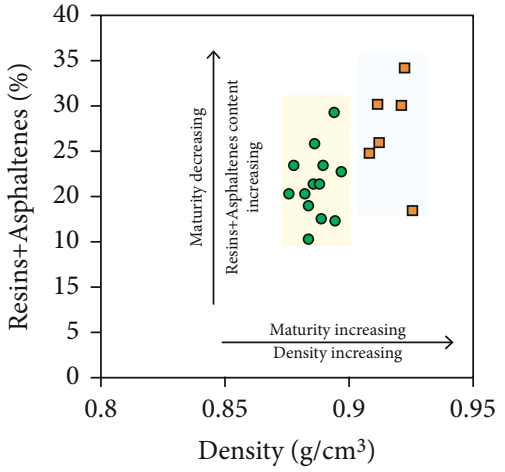

$\mathrm{P}_{2} \mathrm{I}_{2}$

$\square \mathrm{P}_{2} \mathrm{I}_{1}$

(d)

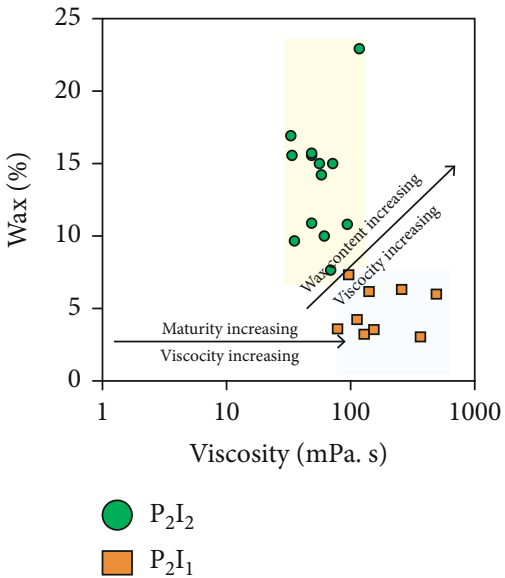

(f)

Figure 9: Cross-diagrams of (a) density versus the content of saturates, (b) viscosity versus the content of saturates, (c) density versus the content of wax, (d) density versus the content of resins + asphaltenes, (e) viscosity versus the content of resins + asphaltenes, and (f) viscosity versus the content of wax, for the crude oil sample in the Lucaogou Formation. 


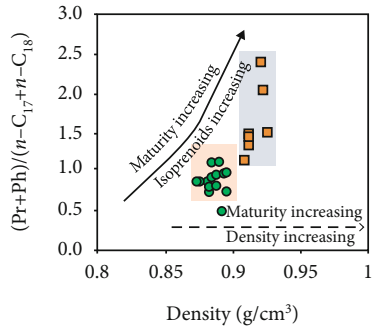

- $\mathrm{P}_{2} \mathrm{I}_{2}$ ․ $\mathrm{P}_{2} \mathrm{I}_{1}$

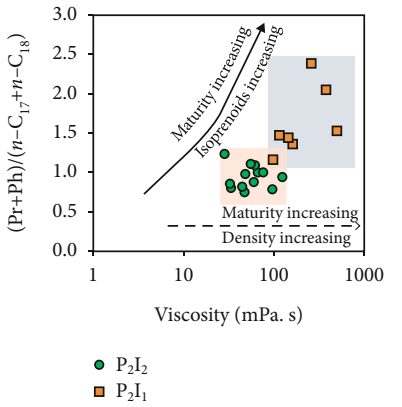

(b)

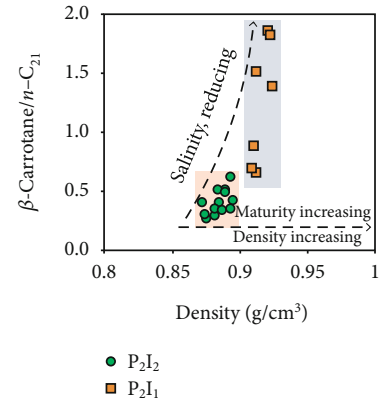

(c)

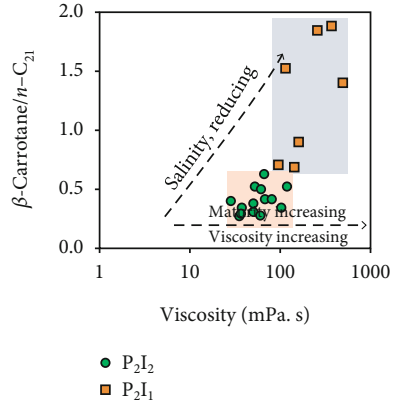

(d)

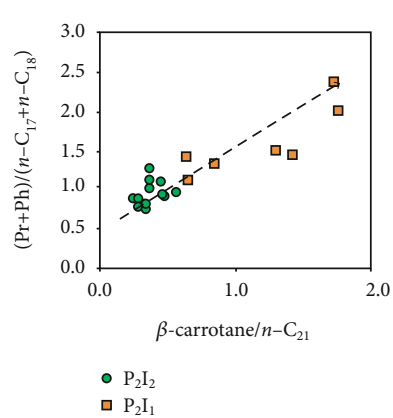

(e)

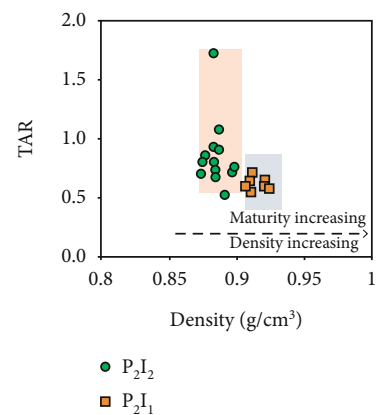

(h)

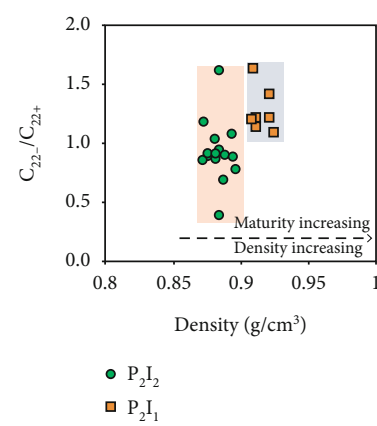

(f)

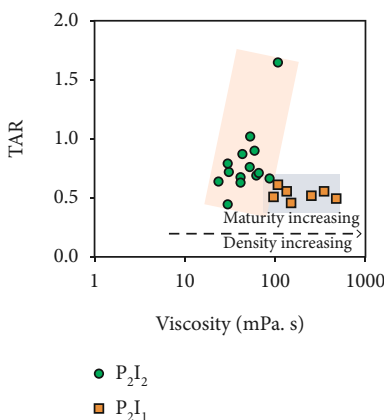

(i)

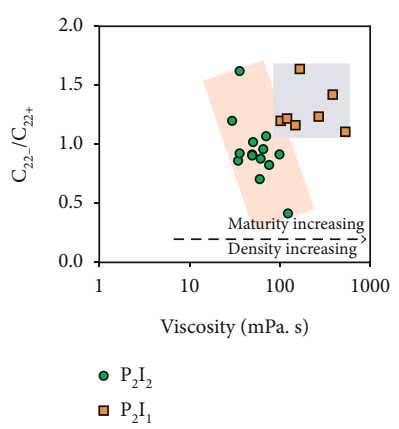

(g)

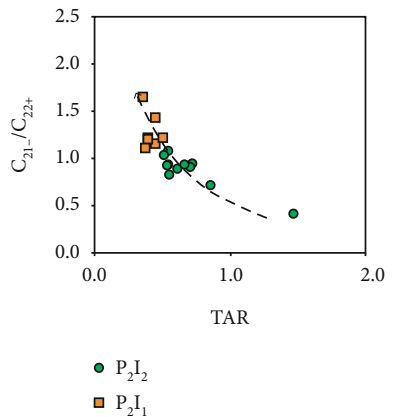

(j)

Figure 10: Cross-diagrams of (a) density and (b) viscosity versus $(\mathrm{Pr}+\mathrm{Ph}) /\left(n-\mathrm{C}_{17}+n-\mathrm{C}_{18}\right)$ ratio; (c) density and (d) viscosity versus $\beta$ carrotane $/ n-\mathrm{C}_{21}$ ratio; (e) $\beta$-carrotane $/ n-\mathrm{C}_{21}$ ratio versus $(\mathrm{Pr}+\mathrm{Ph}) /\left(n-\mathrm{C}_{17}+n-\mathrm{C}_{18}\right)$ ratio; (f) density and (g) viscosity versus $\mathrm{C}_{21}-/ \mathrm{C}_{22}+$ ratio; (h) density and (i) viscosity versus TAR; and (j) TAR versus $\mathrm{C}_{21}-/ \mathrm{C}_{22}+$ ratio, for the crude oil sample in the Lucaogou Formation.

also be relatively different. The CPI (carbon preference index of $n$-alkane), OEP (odd-even predominance of $n$-alkane), $\alpha \alpha \alpha-20 \mathrm{~S} /(20 \mathrm{~S}+20 \mathrm{R}) \mathrm{C}_{29}$ sterane, and $\alpha \beta \beta /(\alpha \beta \beta+\alpha \alpha \alpha) \mathrm{C}_{29}$ sterane ratios can be used to analyze the maturity of organic matter [27-29]. It can be seen from Figure 8 that the maturity, density, and viscosity of the crude oil in the lower sweet spot are generally higher than those of the crude oil in the upper sweet spot (Figure 9). With an increase in the degree of evolution, the saturated hydrocarbon content of oil produced by the same parent type of source rock appears to increase, while the resins and asphaltene decrease. Figures 9(a), 9(b), 9(d), and 9 (e) show that the saturated hydrocarbon content of the crude oil in the upper sweet spot is higher than that of the crude oil in the lower, while the content of resins + asphaltene is lower than that of the crude oil in the lower sweet spot, which is contrary to the evolution of organic hydrocarbon generation. It is thought that a high content of the wax fraction is related to higher plants (Hedburg, 1968), but with additional sources. As can be seen from Figures 9(c) and 9(f), the wax content of the crude oil on the upper sweet spot is significantly higher than that of the crude oil in the lower sweet spot, indicating that the composition of the organic parent material in the source rock of the upper section is significantly different from that of the lower section.

The hydrocarbon $\beta$-carrotane is derived from $\beta$-carotene, which is an accessory pigment of various phototrophs. Therefore, $\beta$-carrotane is mainly related to anoxic and saline lacustrine algae organic matter (Hall et al., 1981; [31, 32]). Because of this, the $\beta$-carrotane $/ n-\mathrm{C}_{21}$ ratio can indicate the degree of enrichment of $\beta$-carrotane in crude oil. $\mathrm{Pr}$ and $\mathrm{Ph}$ are mainly derived from chlorophyll [28]; thus, the $(\mathrm{Pr}+$ $\mathrm{Ph}) /\left(n-\mathrm{C}_{17}+n-\mathrm{C}_{18}\right)$ ratio indicates the relative enrichment of $i$-alkanes ( $\mathrm{Pr}$ and $\mathrm{Ph}$ ) in crude oil. In general, the content of $i$-alkanes decreases with an increase in maturity. 


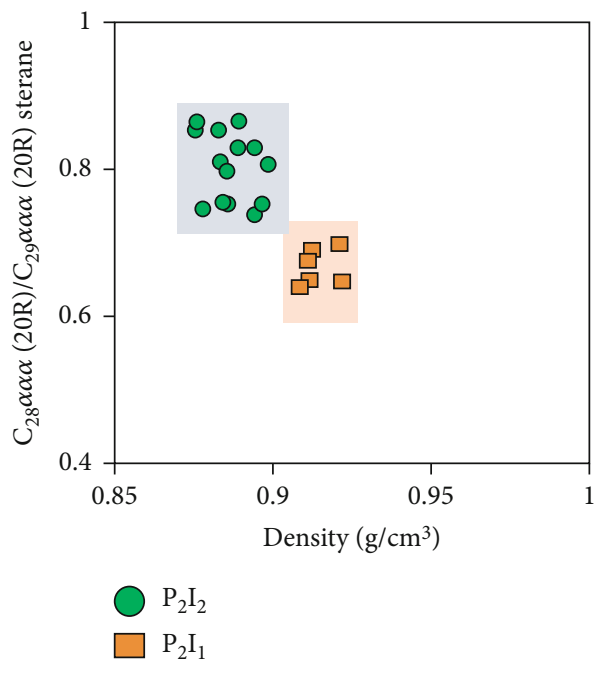

(a)

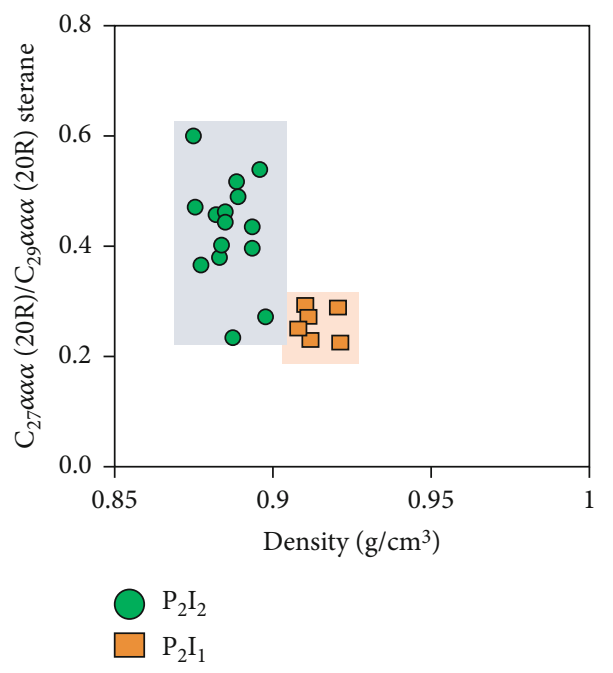

(c)
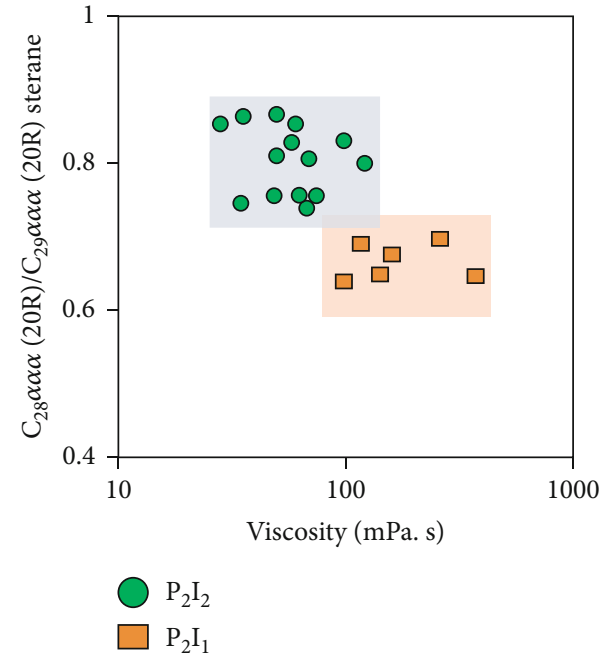

(b)

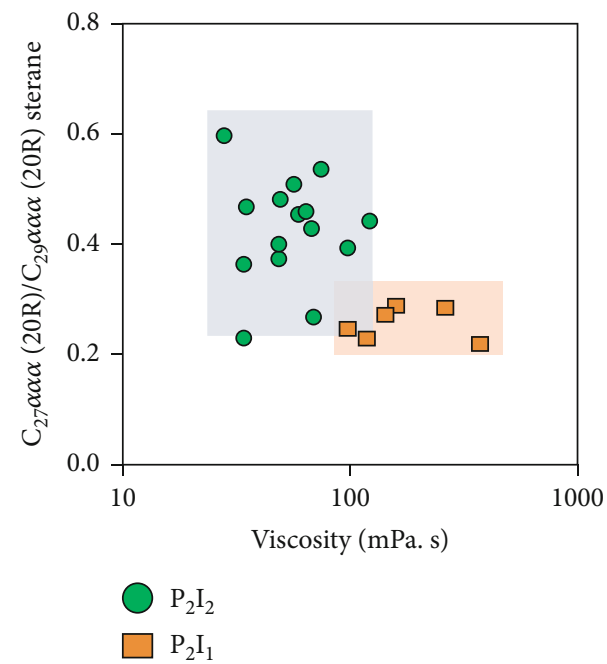

(d)

FIGURE 11: Cross-diagrams of (a) density and (b) viscosity versus $\alpha \alpha \alpha-20 \mathrm{R} \mathrm{C}_{28} / \mathrm{C}_{29}$ sterane ratio and (c) density and (d) viscosity versus $\alpha \alpha \alpha$ $20 \mathrm{R} \mathrm{C}_{27} / \mathrm{C}_{29}$ sterane ratio, for the crude oil sample in the Lucaogou Formation.

In the upper sweet spot for crude oil, the $\beta$-carrotane $/ n$ - $\mathrm{C}_{21}$ values $(0.27-0.59$; average $=0.38)$ and $(\mathrm{Pr}+\mathrm{Ph}) /\left(n-\mathrm{C}_{17}+\right.$ $\left.n-C_{18}\right)$ values $(0.79-1.24$; average $=0.95)$ were higher than those in the lower sweet spot for crude oil $\left(\beta-\right.$ carrotane $/ n-\mathrm{C}_{21}=0.66-1.86, \quad$ average $=1.25 ; \quad(\mathrm{Pr}+$ $\mathrm{Ph}) /\left(n-\mathrm{C}_{17}+n-\mathrm{C}_{18}\right)=1.37-2.38$, average $\left.=1.63\right)$. As shown in Figures $10(\mathrm{a})-10(\mathrm{~d})$, the density and viscosity of crude oil have a good positive correlation with $\beta$-carrotane/ $n-\mathrm{C}_{21}$ and $(\mathrm{Pr}+\mathrm{Ph}) /\left(n-\mathrm{C}_{17}+n-\mathrm{C}_{18}\right)$, indicating that the biological source of $\beta$-carrotane $/ n-\mathrm{C}_{21}$ and $(\mathrm{Pr}+\mathrm{Ph}) /(n$ $\left.-\mathrm{C}_{17}+n-\mathrm{C}_{18}\right)$ may be the reason for the poor physical properties of crude oil in the lower sweet spot. Moreover, the correlation between $\beta$-carrotane $/ n-\mathrm{C}_{21}$ and $(\mathrm{Pr}+\mathrm{Ph}) /(n$ $\left.-\mathrm{C}_{17}+n-\mathrm{C}_{18}\right)$ is extremely good, and the correlation curve nearly penetrates the coordinates' origin (Figure 10(e)), indicating that the two compounds could be possibly sourced from the same parent material.
It is known that the composition and distribution of $n$ alkane and isoprenoids in chained alkanes are intimately related to the sedimentary conditions and OM source ([33]; Peters et al., 2005). Although the $\mathrm{C}_{21}-\mathrm{C}_{22}+$ ratio was influenced by maturation, it can still be used to assess the $\mathrm{OM}$ source of the source rock. Long-chain $n$-alkanes $\left(>n-C_{23}\right)$ are characteristic biomarkers for higher terrestrial plants [34], whereas short-chain $n$-alkanes $(<n$-C20) are predominantly found in algae and microorganisms (Brassell et al., 1978). The TAR (terrigenous/aquatic ratio) index was calculated by using the equation $\left(\mathrm{C}_{27}+\mathrm{C}_{29}+\mathrm{C}_{31}\right) /\left(\mathrm{C}_{15}+\mathrm{C}_{17}+\right.$ $\mathrm{C}_{19}$ ). The prevalence of $n-\mathrm{C}_{27}, n-\mathrm{C}_{29}$, and $n-\mathrm{C}_{31} n$-alkanes implies derivation from epicuticular waxes, which would be most likely synthesized directly by higher plants. The $\mathrm{C}_{21}$ $/ \mathrm{C}_{22}+$ ratio in the upper sweet spot of crude oil (0.40-1.61; average $=0.93)$ was higher than that in the lower sweet spot of crude oil $(1.10-1.62$; average $=1.27)$. The TAR value in 


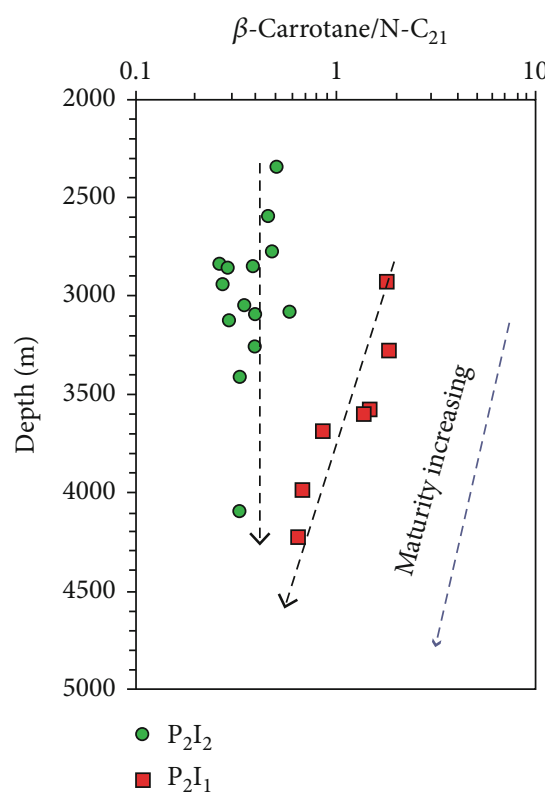

(a)

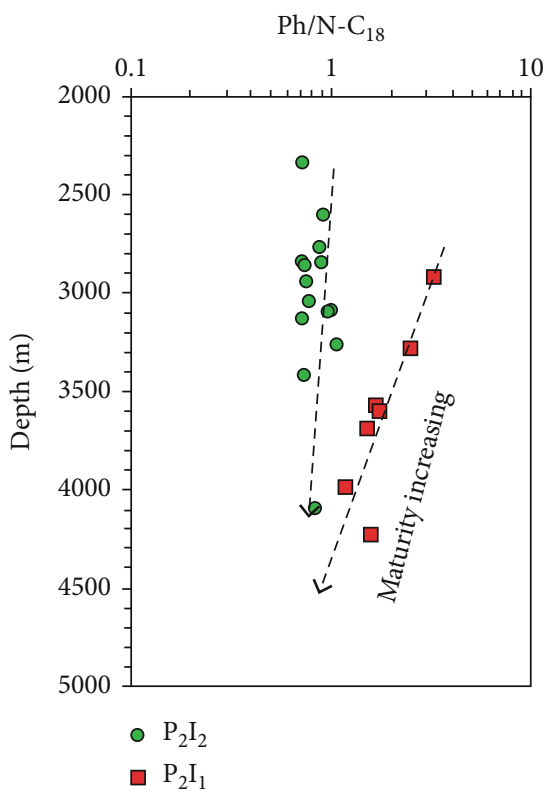

(b)

Figure 12: Cross-plots of (a) $\beta$-carrotane $/ n-\mathrm{C}_{21}$ versus depth and (b) $\mathrm{Ph} / n$ - $\mathrm{C}_{18}$ versus depth.

the upper sweet spot $(0.35-1.54$; average $=0.68)$ was lower than that in the lower sweet spot $(0.37-0.52$; average $=0.44$ ). From Figures 10(f) and $10(\mathrm{~g})$, it can be seen that the density and viscosity of crude oil were positively correlated with $\mathrm{C}_{21}-\mathrm{C}_{22}+$, yet it was negatively correlated with the TAR (Figures 10(h) and 10(i)), indicating that the parent material of source rocks in the lower section was likely substantially different from that in the upper section. This is consistent with the development of laminated algae in the upper source rocks and the development of telalginite in the lower source rocks (Figure 5).

It is known that $\mathrm{C}_{29}$ steranes are commonly derived from terrestrial plants, although terrestrial plants are not a unique source of some aquatic biota, which can also biosynthesize $\mathrm{C}_{29}$ steranes in high abundance, such as brown and green algae (Moldowan et al., 1985; [35]). Therefore, the ratios of $\alpha \alpha \alpha-20 \mathrm{R} \mathrm{C}_{27} / \mathrm{C}_{29}$ sterane and $\alpha \alpha \alpha-20 \mathrm{R} \mathrm{C}_{28} / \mathrm{C}_{29}$ sterane were used to represent the contents of different regular steranes in the crude oils in the upper and lower sweet spots. In the crude oil of the upper sweet spot, $\alpha \alpha \alpha-20 \mathrm{R} \mathrm{C}_{28} / \mathrm{C}_{29}$ sterane values $(0.59-0.87$; average $=0.79)$ and $\alpha \alpha \alpha-20 \mathrm{R} \quad \mathrm{C}_{27} / \mathrm{C}_{29}$ sterane $(0.23-0.60$; average $=0.44)$ were much higher than those in the crude oil of the lower sweet spot $(\alpha \alpha \alpha-20 \mathrm{R}$ $\mathrm{C}_{28} / \mathrm{C}_{29}$ sterane $=0.64-0.70, \quad$ average $=0.67 ; \quad \alpha \alpha \alpha-20 \mathrm{R}$ $\mathrm{C}_{27} / \mathrm{C}_{29}$ sterane $=0.22-0.29$, average $\left.=0.26\right)$. These results indicate a higher concentration of $\mathrm{C}_{29}$ regular steranes in the crude oil in the lower sweet spot. From Figure 11, it can be seen that the density and viscosity of crude oil were negatively correlated with the ratio of $\alpha \alpha \alpha-20 \mathrm{R} \mathrm{C}_{28} / \mathrm{C}_{29}$ sterane to $\alpha \alpha \alpha$-20R $\mathrm{C}_{27} / \mathrm{C}_{29}$ sterane. Combined with the organic petrography observations, it can be seen that the green algae were more abundant in the source rock in the lower section (Figures 5(e) and 5(g)), which is consistent with the fact that the crude oil in the lower sweet spot was rich in $\mathrm{C}_{29}$ regular sterane in the biomarkers of saturated hydrocarbons.
5.3. Relationship between Physical Properties, Migration, and Maturity of Crude Oil. During the enrichment process, if crude oil accumulates in a reservoir without long-distance migration, there will be almost no evident differentiation in the compositions of crude oil containing heavy components that remain in the reservoir, resulting in the deterioration of the physical properties of crude oil in the reservoir. By comparing the biomarker characteristics of crude oils from the upper and lower sweet spots, it was discovered that the crude oils from the upper sweet spot were not significantly different, whereas the biomarker characteristics of the crude oil from the lower sweet spot differed greatly (Figure 6). With the increase in depth, the biomarker characteristics of the crude oil in the lower sweet spot changed regularly, while that of the crude oil in the upper sweet spot did not change significantly (Figure 12). This implies that the crude oil in the upper sweet spot was characterized by migration and accumulation, while the crude oil accumulated in the lower sweet spot resulted from short migration, representing the selfgenerated and self-stored characteristics of the shale oil reservoir. This is consistent with the evident occurrence of crude oil observed in the source rock of the lower section (Figure 5(g)).

When the source rocks have the same source material, the density and viscosity of crude oil decrease with an increase in the maturity of source rocks (Dou et al., 1995). As can be seen from Figure 13, the density and viscosity of crude oil in the upper sweet spot showed no evident correlation with the $\mathrm{C}_{29} \alpha \alpha \alpha 20 \mathrm{~S} /(20 \mathrm{~S}+20 \mathrm{R})$ and $\mathrm{C}_{29} \alpha \beta \beta /(\alpha \beta \beta+\alpha \alpha \alpha)$ sterane ratios, while the density and viscosity of crude oil in the lower sweet spot had a good negative correlation with the $\mathrm{C}_{29} \alpha \alpha \alpha 20 \mathrm{~S} /(20 \mathrm{~S}+20 \mathrm{R})$ and $\mathrm{C}_{29} \alpha \beta \beta /(\alpha \beta \beta+\alpha \alpha \alpha)$ sterane ratios. This indicates that the physical property parameters of the crude oil in the lower sweet spot are affected by the maturity of the source 


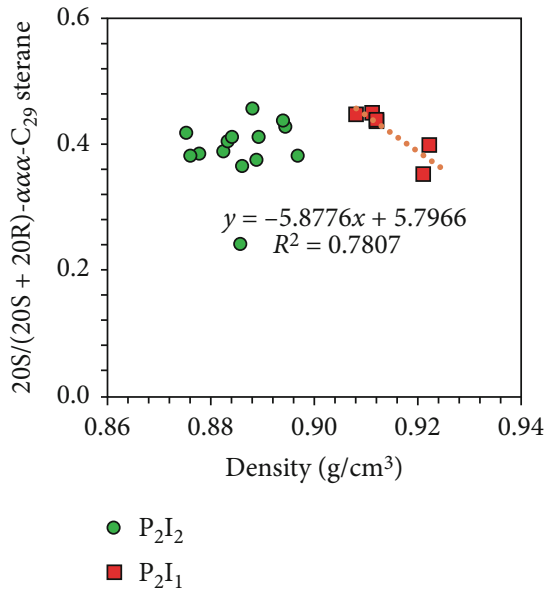

(a)

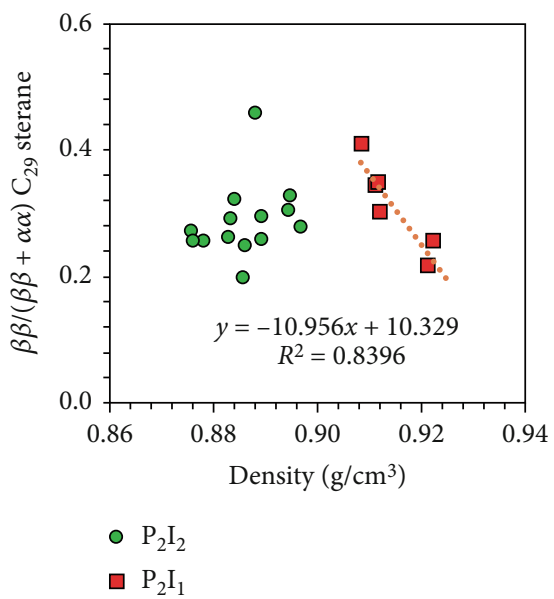

(c)

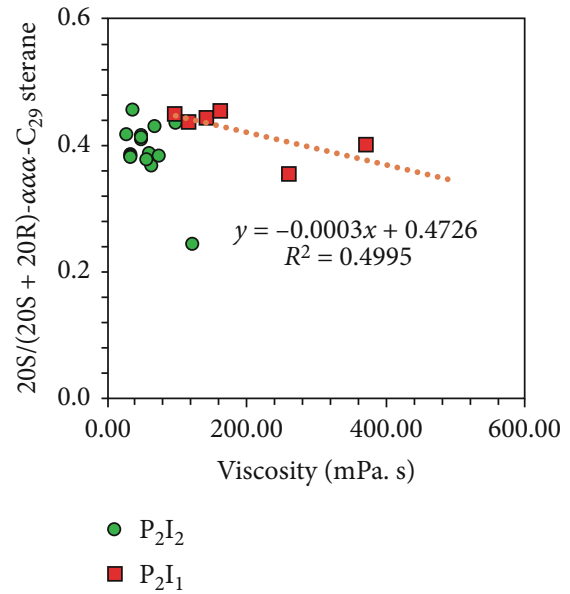

(b)

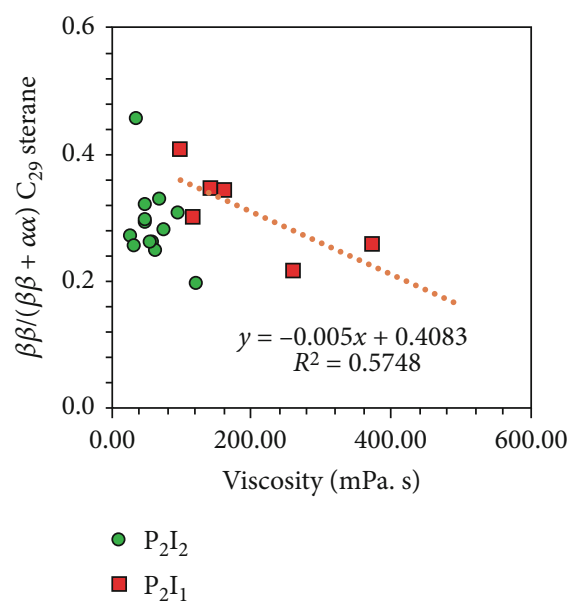

(d)

Figure 13: Cross-diagrams of (a) density and (b) viscosity versus $\mathrm{C}_{29} \alpha \alpha \alpha 20 \mathrm{~S} /(20 \mathrm{~S}+20 \mathrm{R})$ ratio and (c) density and (d) viscosity versus $\alpha \beta \beta /(\alpha \beta \beta+\alpha \alpha \alpha)$ C29 sterane ratio, for the crude oil sample in the Lucaogou Formation.

rock in the lower section, and the lower the maturity of the source rock, the heavier the crude oil.

\section{Conclusions}

Based on the analysis of physical properties, family composition, and biomarkers of crude oils from the upper and lower sweet spots of the Lucaogou Formation in the Jimusaer Sag of the Junggar Basin, it was found that the physical properties of crude oil from the lower sweet spots were poorer than those from the upper sweet spots. However, the $n$-alkanes of the crude oils in the upper and lower sweet spots are relatively complete and have an evident odd-to-even predominance, indicating that the poor physical properties of crude oil in the study area are not related to biodegradation.

By comparing the physical properties of crude oil with biogenic parameters of saturated hydrocarbon biomarkers, it was found that the physical properties of crude oils in the upper and lower sweet spots were affected by the parent material. Combined with the organic petrological observation of source rocks in the upper and lower sections, it was indicated that the telaginite (green algae) present in the source rocks of the lower section is primarily responsible for the variation of crude oil quality in the lower sweet spot.

Furthermore, the saturated hydrocarbon biomarkers of crude oil in the upper sweet spot were found to have similar characteristics, while the saturated hydrocarbon biomarkers of crude oil in lower sweet spots showed regular changes with increasing depth. Thus, it was revealed that the enrichment of crude oil in the lower sweet spot has evident characteristics of self-sourced and self-stored configuration, while the crude oil in the upper sweet spot has experienced a certain degree of migration. At the same time, under the condition of having the same parent material source, it was thus inferred that the crude oil in the upper sweet spot was also affected by the maturity of adjacent source rocks; in that, the lower the maturity of source rocks, the worse the physical properties of the crude oil produced.

\section{Data Availability}

Data will be submitted as needed. 


\section{Conflicts of Interest}

The authors declare that they have no conflicts of interest.

\section{Acknowledgments}

The authors are thankful for the support from the Chinese National Oil and Gas major project (project number: 2017ZX05008006-003) and for the guidance provided by the China University of Petroleum (Beijing), as well as the experimental and testing supports sponsored by the State Key Laboratory of Petroleum Resources and Prospecting, Beijing.

\section{References}

[1] L. Kuang, Y. Tang, D. Lei et al., "Formation conditions and exploration potential of tight oil in the Permian saline lacustrine dolomitic rock, Junggar Basin, NW China," Petroleum Exploration and Development, vol. 39, no. 6, pp. 700-711, 2012.

[2] W. Z. Zhao, S. Y. Hu, L. H. Hou et al., "Types and resource potential of continental shale oil in China and its boundary with tight oil," Petroleum Exploration and Development, vol. 4, pp. 1-10, 2020.

[3] Z. Cao, G. D. Liu, Y. H. Kong et al., "Lacustrine tight oil accumulation characteristics: Permian Lucaogou Formation in Jimusaer Sag, Junggar Basin," International Journal of Coal Geology, vol. 153, pp. 37-51, 2016.

[4] Z. Cao, G. D. Liu, B. L. Xiang et al., "Geochemical characteristics of crude oil from a tight oil reservoir in the Lucaogou Formation, Jimusar Sag, Junggar Basin," AAPG Bulletin, vol. 101, no. 1, pp. 39-72, 2017.

[5] A. R. Carroll, "Upper Permian lacustrine organic facies evolution, Southern Junggar Basin, NW China," Organic Geochemistry, vol. 28, no. 11, pp. 649-667, 1998.

[6] X. Xie, T. Borjigin, Q. Zhang et al., "Intact microbial fossils in the Permian Lucaogou Formation oil shale, Junggar Basin, NW China," International Journal of Coal Geology, vol. 146, pp. 166-178, 2015.

[7] B. L. Xiang, E. T. Li, X. W. Gao et al., "Petroleum generation kinetics for Permian lacustrine source rocks in the Junggar Basin, NW China," Organic Geochemistry, vol. 98, pp. 1-17, 2016.

[8] B. L. Xiang, J. D. Liao, N. Zhou et al., "Geochemical characteristic of the source rock of Lucaogou Formation in Ji174 well, Junggar Basin," Science \& Technology and Engineering, vol. 13, pp. 9636-9640, 2013.

[9] L. C. Kuang, Z. C. Sun, M. Ouyang, Q. S. Chang, and Z. L. Wang, "Complication lithology logging identification of the Lucaogou tight oil reservoir in Jimusaer Depression," Well Logging Technology, vol. 37, pp. 638-642, 2013.

[10] Z. Qiu, C. N. Zou, D. Z. Dong et al., "Petroleum system assessment of conventional-unconventional oil in the Jimusar Sag, Junggar Basin, Northwest China," Journal of Unconventional Oil and Gas Resources, vol. 16, pp. 53-61, 2016.

[11] K. L. Xi, Y. C. Cao, R. K. Zhu et al., "Rock types and characteristics of tight oil reservoir in Permian Lucaogou Formation, Jimsar Sag," Acta Petrolei Sinica, vol. 36, pp. 1495-1507, 2015.

[12] Z. Qiu, H. F. Tao, C. N. Zou, H. Y. Wang, H. J. Ji, and S. X. Zhou, "Lithofacies and organic geochemistry of the middle
Permian Lucaogou Formation in the Jimusar Sag of the Junggar Basin, NW China," Journal of Petroleum Science and Engineering, vol. 140, pp. 97-107, 2016.

[13] Y. Zejun, Permian Geological Architecture and Formation Mechanism of Eastern Junggar Basin, China University of Geosciences (Beijing), Beijing, 2018.

[14] S. Fang, H. Xu, Y. Song, J. Li, L. Liu, and J. Zhang, "Characteristics and evolution of the composite petroleum system in Jimsar Depression, Eastern Junggar Basin," Acta Geoscientica Sinica, vol. 26, no. 3, pp. 259-264, 2005.

[15] Z. Shaomin, C. Yingchang, R. Zhu et al., "Lithofacies classification of fine-grained mixed sedimentary rocks in the Permain Lucaogou Formation, Jimsar Sag, Junggar Basin," Earth Science Frontiers, vol. 25, no. 4, pp. 198-209, 2018.

[16] G. Gao, W. Zhang, B. Xiang, G. Liu, and J. Ren, “Geochemistry characteristics and hydrocarbon-generating potential of lacustrine source rock in Lucaogou Formation of the Jimusaer Sag, Junggar Basin," Journal of Petroleum Science and Engineering, vol. 145, pp. 168-182, 2016.

[17] H. Bai, X. Pang, L. Kuang et al., "Hydrocarbon expulsion potential of source rocks and its influence on the distribution of lacustrine tight oil reservoir, middle Permian Lucaogou Formation, Jimsar Sag, Junggar Basin, Northwest China," Journal of Petroleum Science and Engineering, vol. 149, pp. 740-755, 2017.

[18] J. Cao, L. W. Xia, T. T. Wang, D. M. Zhi, Y. Tang, and W. W. Li, "An alkaline lake in the Late Paleozoic Ice Age (LPIA): a review and new insights into paleoenvironment and petroleum geology," Earth Science Reviews, vol. 202, p. 103091, 2020.

[19] L. W. Xia, J. Cao, M. Wang, J. L. Mi, and T. T. Wang, "A review of carbonates as hydrocarbon source rocks: basic geochemistry and oil-gas generation," Petroleum Science, vol. 16, no. 4, pp. 713-728, 2019.

[20] P. C. Hackley, N. Fishman, T. Wu, and G. Baugher, "Organic petrology and geochemistry of mudrocks from the lacustrine Lucaogou Formation, Santanghu Basin, northwest China: application to lake basin evolution," International Journal of Coal Geology, vol. 168, pp. 20-34, 2016.

[21] R. L. Silva, J. G. Mendonça Filho, L. V. Duarte, T. F. Silva, and A. C. Azerêdo, Preliminary Evaluation of Age-, Source- and Thermal Maturity Related Biomarkers at the Early-Late Pliensbachian Transition in the Most Proximal Sector of the Hemipelagic Setting of the Lusitanian Basin (Portugal), Special Meeting of the Société Géologique De France in Honor of Serge Elmi, 2010.

[22] J. Connan, Biodegradation of Crude Oils in Reservoirs-A-non. Advances in Petroleum Geochemistry, London: Academic Press, 1984.

[23] S. Z. Hu, D. M. Zhang, T. Jing, and J. N. Gu, "Review of the genesis of heavy oil," Bulletin of Geological Science and Technology, vol. 2, pp. 97-100, 2009.

[24] J. K. Volkman, R. Alexander, R. I. Kagi, and G. W. Woodhouse, "Demethylated hopanes in crude oils and their applications in petroleum geochemistry," Geochimica et Cosmochimica Acta, vol. 47, no. 4, pp. 785-794, 1983.

[25] A. M. K. Wardroper, J. R. Maxwell, and R. J. Morris, "Sterols of a diatomaceous ooze from Walvis Bay," Steroids, vol. 32, no. 2, pp. 203-221, 1978.

[26] J. Wu, H. Dujie, X. Huiyuan et al., "Oil's light hydrocarbon, geochemical characteristics and sources in Xihu Sag, the East 
China Sea Basin," Journal of Northeast Petroleum University, vol. 39, no. 5, pp. 23-31, 2015.

[27] D. W. Waples, Geochemistry in Petroleum Exploration. Boston, inter, Human Resources and Develop. Co., 1985.

[28] K. E. Peters and J. M. Moldowan, The Biomarker Guide: Interpreting Molecular Fossils in Petroleum and Ancient Sediments, Prentice-Hall, Englewood Cliffs, N. J, 1993.

[29] K. E. Peters, C. C. Walters, and J. M. Moldowan, The Biomarker Guide. Second Edition. Biomarkers and Isotopes in Petroleum Systems and Earth History (II), University Press, Cambridge, 2005.

[30] K. E. Peters, C. C. Walters, and J. M. Moldowan, The Biomarker Guide: Interpreting Molecular Fossils in Petroleum and Ancient Sediments, Second Ed, Cambridge University Press, Cambridge, 2005.

[31] Z. S. Jiang and M. G. Flower, "Carotenoid derived alkanes in oil from Northwestern China," Advances in Organic Geochemistry, Organic Geochemistry, vol. 10, pp. 831-839, 1986.

[32] P. B. Hal, "The distribution of cyclic alkanes in two lacustrine deposits," in Advances in Organic Geochemistry, 1983.

[33] J. M. Moldowan, P. Sundararaman, and M. Schoell, "Sensitivity of biomarker properties to depositional environment and/or source input in the Lower Toarcian of SW-Germany," Organic Geochemistry, vol. 10, no. 4-6, pp. 915-926, 1986.

[34] G. Eglinton and R. G. Hamilton, "Leaf epicuticular waxes," Science, vol. 156, no. 3780, pp. 1322-1335, 1967.

[35] J. K. Volkman and J. R. Maxwell, "Acyclic isoprenoids as biological markers," in Biological Markers in the Sedimentary Record, R. B. Johns, Ed., pp. 1-42, Elsevier, Amsterdam, 1986. 